DOI:

УДК 349.41:349.6

\author{
Ольга Зигрій, \\ к. е. н., дочент кафедри \\ циивільного права і процесу \\ Тернопільського національного \\ економічного університету \\ ORCID: https://orcid.org/0000-0001-7092-5306
}

\title{
Юлія Ковальчук,
}

викладач кафедри фундаментальних

і спеціальних дисциилін

Чортківського навчально-наукового

інституту підприсмництва і бізнесу

Тернопільського начіонального

економічного університету

\section{Тетяна Кондрат,}

студентка юридичного факультету

Тернопільського національного економічного

університету

\section{ПРАВОВЕ РЕГУЛЮВАННЯ ПРАВА ВЛАСНОСТІ НА ЛІСОВІ УГІДДЯ ТА ОБ'ЄКТИ РОСЛИННОГО СВІТУ}

Звернено увагу на правову базу регулювання правовідносин з приводу власності на лісові угіддя та об'єкти рослинного світу. На основі чинного законодавства та юридичної літератури проведено комплексний аналіз підстав набуття права власності на досліджувані об'єкти. Дано правову характеристику особливостям реалізації иъього права. Проаналізовано співвідношення норм чинного земельного та лісового законодавства. Наведено різні погляди на ие питання, розглянуто відповідні нормативні акти, обговорено різні шляхи реформування та оцінено їх перспективи. Проведено урізноманітнення сучасної структури власності на ліси, яка фактично є тільки державною. Подано особливість створення комунального сектору як оптимального варіанту. Обтрунтовано та запропоновано внесення змін до законодавчих актів з метою надання лісових угідь у комунальну власність.

Ключові слова: лісові угіддя, рослинний світ, представники рослинного світу, право власності на лісові угіддя, об'єкти рослинного світу.

\section{Зыгрий О., Ковальчук Ю., Кондрат Т.}

Правовое регулирование права собственности на лесные угодья и объектов растительного мира

Обращено внимание на правовую базу регулирования правоотношений по поводу собственности на лесные угодья и объекты растительного мира. На основе действующего законодательства и юридической литературы проведен комплексный анализ оснований приобретения права собственности на исследуемые объекты. Дана правовая характеристику особенностям реализации этого права. Проанализировано соотношение норм действующего земельного и лесного законодательства. Приведены различные взгляды на этот вопрос, рассмотрены соответствующие нормативные акты, обсуждены различные пути реформирования и оиенена их перспективы. Проведено разнообразия современной структуры собственности на леса, которая фактически является исключительно государственной. Подано особенность создания коммунального сектора в качестве оптимального варианта. Обосновано и предложено внесение ряда изменений в законодательные акты с иелью предоставления лесных угодий в коммунальную собственность.

Ключевые слова: лесные угодья, растительный мир, представители растительного мира, право собственности на лесные угодья, объекты растительного мира.

Zykhriузыгрий О., Ковальчук Ю., Кондрат T.

Legal regulation of the ownership of the forest land and the vegetables of the vegetable world

At the present stage of development of state-building in Ukraine, one of the leading places is the legal regulation of public relations in the field of forestry and the legal regulation of objects of the flora. In the context of further

( Ольга Зигрій, Юлія Ковальчук, Тетяна Кондрат, 2019 
diversification of forest ownership forms, forest areas used by agricultural enterprises are of particular importance. They potentially serve as a basis for the formation of communal property forests. The purpose of this article is to analyze the theoretical provisions and practical recommendations for the realization of property rights, in particular communal property, in the flora objects listed in the Green Paper of Ukraine.

The article draws attention to the legal basis for regulating legal relations regarding ownership of forest lands and flora. On the basis of the current legislation and legal literature, a comprehensive analysis of the grounds for the acquisition of ownership of the objects under study. The legal characteristic is given to the peculiarities of realization of this right. The relation between the norms of the current land and forest legislation is analyzed. Different views on this issue are presented, relevant normative acts are considered, different ways of reform are discussed and their prospects are evaluated. The modern ownership structure of forests, which is in fact exclusively state owned, has been diversified. The peculiarity of creating the municipal sector as an optimal variant is presented. A number of amendments to the legislative acts are justified and proposed in order to provide forest land in communal property. We offer the right for territorial communities to own, use and manage at their own discretion and in the interests of objects owned by the community through local governments in compliance with environmental requirements. Fixing it in the floristic legislation of this definition will help to improve it.

Keywords: forest lands, flora, representatives of the flora, ownership of the forest lands, objects of flora.

Постановка проблеми. В Україні простежується катастрофічне зменшення територій степових екосистем й природних лісів. За площею лісів та запасів деревини Україна є державою з дефіцитом лісових ресурсів. Ліси займають понад 15,7\% території держави. Саме зменшення площ навколишнього середовища відбувається внаслідок вирубки лісів, розораності земель з подальшою зміною їх цільового призначення.

Розмежування охорони й захисту права власності на природні об’єкти полягає у часі їх настання, способах здійснення, засобах реалізації, органах здійснення тощо. Так, охорона права власності виникає з моменту прийняття правових норм, що оберігають відносини власності, і припиняється разом із скасуванням охоронних правових норм. Захист права власності настає з моменту порушення права і діє у межах строків, встановлених для його захисту. Отже, охорона права власності, в т. ч. на природні об'єкти, притаманна праву власності в об'єктивному розумінні. Захист права власності на природні ресурси властивий праву власності в суб'єктивному розумінні.

Серед багатьох проблем юридичної науки за своєю актуальністю і складністю особливе місце посідає законодавче забезпечення права власності на природні ресурси й комплекси, зокрема на особливо цінні та охоронювані об'єкти - об'єкти рослинного світу, занесені до Зеленої книги України. Чинне законодавство не повною мірою регулює відносини, що виникають у процесі здійснення права власності, зокрема комунальної, на об’єкти рослинного світу, занесені до Зеленої книги України, що й обумовлює актуальність публікації.

Аналіз наукових досліджень та публікацій. Слід зазначити, що у працях В. І. Андрейцева, А. П. Гетьмана, П. Ф. Кулинича, В. В. Носіка, В. П. Непийводи, Ю. С. Шемшученка, Н. Г. Юрчишин грунтовно розкривалися окремі питання права власності на природні ресурси й комплекси $[1 ; 2 ; 14 ; 15 ; 19 ; 20$; 24; 25]. Однак аспекти права комунальної власності на об'єкти рослинного світу, занесені до Зеленої книги України, потребують дослідження.

Мета статті полягає в аналізі теоретичних положень і практичних рекомендацій щодо реалізації права власності, зокрема комунальної, на об’єкти рослинного світу, занесені до Зеленої книги України.

Виклад основного матеріалу дослідження. Поняття «право комунальної власності» сформульовано в законодавстві України недавно. У 1991 р. Кабінет Міністрів України прийняв Постанову № 311 «Про розмежування державного майна України між загальнодержавною (республіканською) власністю i власністю адміністративно-територіальних одиниць (комунальною власністю)», на підставі якої були первісно сформовані об’єкти права комунальної власності [22]. Конституційний договір між Верховною Радою і Президентом України «Про основні засади організації і функціонування державної влади і місцевого самоврядування в Україні на період до прийняття нової Конституції України» (ст. 5) та Закон України «Про власність» від 07.02.1991 р. також містили цю форму власності [12; 3].

Пріоритетним є положення Конституції України, у ст. 142 якої встановлено, що матеріальною й фінансовою основною місцевого самоврядування виступає земля та ін. природні ресурси, які знаходяться у власності територіальних громад сіл, селищ, міст, районів у містах та об'єкти їх спільної власності, що перебувають в управлінні районних і обласних рад [13]. Усю повноту правочинностей володіння, користування та розпорядження щодо об'єктів комунальної власності, в т. ч. лісів, земельних лісових ділянок, згідно 3 п. 30 ч. 1 ст. 26 і ч. 3 ст. 60 Закону «Про місцеве самоврядування в Україні» здійснюють відповідні органи місцевого самоврядування [5]. Основну роль у визначенні правових засад права комунальної влас- 
Цивільне право і цивільний процес. Сімейне право. Трудове право. Міжнародне приватне право. Господарське право. Господарсько-процесуальне право.

ності відіграє чітко сформульована загальна дефініція зазначеного поняття: право територіальної громади володіти, цілеспрямовано, економно й ефективно користуватися та розпоряджатися на свій розсуд та у своїх інтересах майном через органи місцевого самоврядування.

Основним комплексним нормативним актом екологічного законодавства є Закон України від 25.06.1991 р. за № 1264-XII «Про охорону навколишнього природного середовища» [7]. У ст. 4 розглядається питанням права власності на природні ресурси, які є власністю Українського народу. Однак про визначення ін. форм власності на природні ресурси в Законі не йдеться.

Щодо права власності на природні рослинні угруповання (рослинний світ) виникає чимало проблем, які потребують вирішення. Законодавець у Положенні про Зелену книгу України, затвердженому Кабінетом Міністрів України на виконання Закону України «Про рослинний світ», не встановив право власності на природні рослинні угруповання, які занесені до Зеленої книги України [21]. Враховано їх особливий статус, вимоги щодо охорони цих угруповань під час розробки нормативно-правових актів. Якщо звернутися до Закону України «Про природно-заповідний фонд», то там є тільки загальні положення щодо права власності на території й об'єкти природно-заповідного фонду. У процесі дослідження цього питання слід за основу брати лісове законодавство.

У Лісовому кодексі України не передбачено досліджувану форму власності. Проте земельне законодавство (Постанова Кабінету Міністрів України від 01.08.2002 р., № 1482 «Про затвердження тимчасового порядку розмежування земель права державної і комунальної власності» [22]) визначає категорії земель, які змінюють форми власності. Комунальна власність на землі лісового фонду в межах населених пунктів - це власність територіальних громад сіл, селищ і міст. Землі лісового фонду поза межами населених пунктів - державна власність.

У 2004 р. прийнято Закон України «Про розмежування земель державної та комунальної власності» № 1457-IV, в якому при розмежуванні земель державної й комунальної власності до останніх передаються [23]:

- усі земельні ділянки в межах населених пунктів, крім земель приватної, державної власності;

- земельні ділянки за межами населених пунктів, з розташованими об'єктами комунальної власності;

- землі запасу, відповідно до законодавства України, які раніше були передані територіальним громадам сіл, селищ і міст;

- земельні ділянки, на яких розміщені об'єкти нерухомого майна, що є спільною власністю територіальної громади та держави.

Зазначені положення не виокремлюють землі лісового фонду як землі комунальної власності. ст. 6 вище названого Закону вказує, що при розмежуванні земель державної та комунальної власності не можуть передаватися до земель комунальної власності землі лісового фонду за межами населених пунктів. Інших приписів немає.

Лісовий кодекс України (ст. 7) подає 3 форми власності на ліси - це державна, комунальна та приватна [11; 18]. У статтях 9, 11 зазначається, що в комунальній власності перебувають ліси в межах населених пунктів, крім державної та приватної власності, та інші ліси, набуті чи віднесені до їх об'єктів в установленому законом порядку.

Територіальні громади реалізують права на ліси безпосередньо або через утворені ними органи місцевого самоврядування. Ст. 11 ЛК України подає, що таке право набувається в разі розмежування в установленому законом порядку земель державної та комунальної власності за умови передачі земельних ділянок 3 державної власності в комунальну та за ін. підстав, не заборонених законом. В узагальненому порядку законодавець подає підстави виникнення комунальної власності. Розмежування земель державної та комунальної власності має відбуватися в порядку, передбаченому Законом України «Про розмежування земель державної та комунальної власності». Така дія мала бути одноразовою і повинна призвести до первинного формування земельної й пов'язаної з нею лісової власності територіальних громад, забезпечивши дотримання державних інтересів. Передача земельних ділянок з державної власності в комунальну здійснюється відповідно до ч. 4 ст. 83 і ст. 117 ЗК у порядку, передбаченому ст. 123 зазначеного Кодексу [16, с. 34].

На сьогодні вищезазначений Закон України «Про розмежування земель державної та комунальної власності» скасовано прийнятим Законом «Про внесення змін до деяких законодавчих актів України щодо розмежування земель державної та комунальної власності» від 06.09.2012 р. за № 5245-VI, відповідно до якого до землі комунальної власності віднесені [22]:

- земля, на якій розташовані споруди, будівлі, ін. об’єкти нерухомого майна комунальної власності певної територіальної громади, яка перебуває у постійному користуванні органів місцевого самоврядування, установ та організацій, комунальних підприємств;

- всі ін. землі, що розташовані в межах певних населених пунктів, які віднесені у процесі розмежування до земель власності державної. 
Зигрій О., Ковальчук Ю., Кондрат Т.

Правове регулювання права власності на лісові угіддя та об'єкти рослинного світу

У ч. 4 ст. 83 ЗК України подано землі комунальної власності, котрі не можуть перебувати у приватній власності:

- землі природно-заповідного фонду, історико-культурного й оздоровчого призначення. Ця категорія земель має особливу оздоровчу, наукову, екологічну, естетичну та історико-культурну цінність;

- землі лісогосподарського призначення та ін..

Науковці та практики загалом позитивно оцінюють відповідні зміни й доповнення, які останнім часом запропоновані законодавцем, внесення їх до відповідних спеціальних законів, наприклад, до ЗК України. ЛК України жодних додаткових положень не містив. Право комунальної власності на ліси нерозривно пов'язане з відповідним правом власності на земельні лісові ділянки. В чинному законодавстві немає окремого виду правовстановлювальних документів про права комунальної та інших форм власності на ліси.

У ст. 11 ЛК набуття права комунальної власності на ліси пов'язується саме з розмежуванням чи переходом прав на певні земельні ділянки [11; 16, с. 28].

Загальні вимоги щодо захисту й охорони права власності на природні об'єкти містяться в конституційних нормах. Так, згідно із ст. 14 Конституції, земля $є$ основним національним багатством, що перебуває під особливою охороною держави. Безумовно, у наведеній нормі закладена не тільки правова охорона землі як об’єкта права власності, а й усі інші засоби охорони земельних ресурсів. Положення ст. 41 Основного Закону про те, що «ніхто не може бути протиправно позбавлений права власності», однаковою мірою стосується як до охорони, так і до захисту права власності. Вимоги вказаної норми про те, що використання власності не може завдавати шкоди правам, свободам та гідності громадян, інтересам суспільства, погіршувати екологічну ситуацію і природні якості землі, визначають межі здійснення суб'єктивного права власності на природні об'єкти та забезпечення його захисту. Окремі положення про захист і охорону права власності на природні об'єкти можна знайти в природоохоронному законі. Так, відповідно до ст. 5 Закону «Про охорону навколишнього природного середовища», під державну охорону підлягають ті природні ресурси, які залучені в господарський обіг і не були використані в народному господарстві в певний період (земля, надра, води, ліси, об’єкти рослинного й тваринного світу), ландшафти та інші природні об'єкти та комплекси [14, с. 68-69] .

Сучасне екологічне законодавство (зокрема, ч. 2 ст. 79 ЗК України), що грунтується на традиціях цивільного законодавства, встановлює, що право власності на земельну ділянку поширюється в ії межах на поверхневий (грунтовий) шар, а також на водні об’єкти, ліси й багаторічні насадження, що на ній знаходяться, якщо інше не зазначено в законі й не порушує права інших осіб. Відповідно й ЛК України, як уже зазначалося, прийняв указані положення. 3 огляду на поняття самостійності законодавства лісового як одного із складових екологічного законодавства, як і земельного, іноді недоцільно так однозначно сприймати та копіювати деякі приписи цивільного законодавства. Законодавець надає пріоритет саме екологічному значенню лісів і водночас указує на ліс як сировинну базу лісової й лісопереробної промисловості. Основною є думка, що особливості вказаного правового режиму власності мають визначити не землі, на яких зростають ліси, а ліси.

Науковці в процесі дослідження правових аспектів права комунальної власності на ліси зверталися до визначення критеріїв, притаманних цій формі власності. Так, зазначається, що в законодавстві (ст. 9 ЛК України) визначено загальні критерії належності лісів до об’єктів комунальної власності: те, що вони знаходяться в межах населеного пункту і не перебувають у державній і приватній власності. Отже, норма містить відмежування лісів, що належать до власності комунальної [11; 16, с. 28].

Щодо першого критерію, то в науково-практичній літературі він розглянутий доволі докладно. Так, цілком слушно стверджується, що підставою віднесення відповідних лісових ділянок до об'єктів комунальної власності $\epsilon$ розташування їх у межах населеного пункту. Відповідно до ст. 85 Конституції України, ст. 175 ЗК на підставі належним чином розроблених і погоджених проєктів землеустрою межі міст затверджує Верховна Рада України, а межі сіл і селищ згідно зі ст. 43 Закону «Про місцеве самоврядування в Україні» - обласні ради [11, с. 28].

Щодо другого критерію, який науковці визначають як суто юридичний - неперебування лісів у державній або приватній власності, то зазначимо таке. Факт перебування лісів у приватній власності згідно зі ст. 13 ЛК України посвідчується державним актом про право власності на землю, виданим на відповідну земельну ділянку, або в інший спосіб, передбачений законодавством. Отже, встановлення цього факту не викликає особливих складнощів. Певні проблеми можуть бути лише у разі виникнення права власності на земельні ділянки на підставі цивільно-правових угод без видачі державних актів у зв'язку з набуттям чинності 31 травня 2009 р. змін до статей 125 та 126 ЗК [11, с. 29].

Як виважено вказують учені, до розмежування земель державної і комунальної власності й оформлення відповідних актів на останні чітко визначити належність лісів у населених пунктах неможливо [11, 
Цивільне право і цивільний процес. Сімейне право. Трудове право. Міжнародне приватне право. Господарське право. Господарсько-процесуальне право.

с. 29]. Одночасно в науковій правовій літературі наводяться практичні рекомендації щодо можливого вирішення вказаної проблеми, а саме: до моменту розмежування лісів комунальної та державної власності положення ч. 1 ст. 9 ЛК України необхідно застосовувати в системному зв'язку з п. 12 Перехідних положень ЗК України щодо визначення правочинностей органів місцевого самоврядування в частині надання лісів у межах населених пунктів у власність або користування [11, с. 30]. Учені наголошують, що загалом поділ природних ресурсів на об'єкти республіканського й місцевого значення вбачається дуже плідним, оскільки він утворює відправні моменти для наступного правового регулювання питань власності на ці ресурси [17, c. 137]. Також було висловлено думку про можливість визначити перелік лісів державної власності в межах населених пунктів; це ліси: які перебувають у віданні державних лісогосподарських чи інших державних підприємств і які повністю або частково знаходяться в межах населених пунктів; на земельних ділянках, що забезпечують діяльність державних органів, НАН України, державних галузевих академій наук, вищих професійно-технічних держав них закладів; у складі об'єктів природно-заповідного фонду загальнодержавного значення. Хоча цей перелік не виключає можливості віднесення до лісів державного значення в населених пунктах та інших лісів з урахуванням вимог законодавства й місцевих умов [16, с. 29].

Важливо, що до змісту Закону України «Про розмежування земель державної так комунальної власності» ввійшли принципи такого розмежування.

Так, зазначається, що розмежування земель державної й комунальної власності здійснюється за принципами:

- забезпечення безпеки держави;

- поєднання державних та місцевих інтересів;

- забезпечення рівності права власності на землю територіальних громад і держави;

- безоплатності;

- обгрунтованості;

- досягнення збалансованого співвідношення економічних та екологічних інтересів суспільства;

- забезпечення раціонального використання й охорони земель [9].

Ці принципи розмежування мають відображати його основні властивості й особливості, провідні засади процесу його регламентування.

Висновки. Критеріями виокремлення лісів досліджуваної форми власності необхідно встановити територіальну ознаку й суспільне значення останніх. Використання цих закріплених у законі критеріїв дасть змогу належним чином реалізовувати відповідні норми, що приведе до поєднання економічної ефективності із соціальною справедливістю. Визначання таких критеріїв буде доцільним з огляду не тільки на економічне значення лісів, й більшою мірою на їх рекреаційний потенціал і на те, що вони як середовище буття людини оберігають атмосферне повітря від забруднення, формують клімат тощо. Крім того, зважаючи на те, що природні рослинні угруповання, занесені до Зеленої книги України, визначаються за певними категоріями та статусом. Щодо останнього, то вирізняють саме рідкісні, зникаючі та типові природні рослинні угруповання. У процесі визначення досліджуваного права власності необхідно враховувати і такий критерій, як належність зазначених об'єктів до конкретних категорій, і враховувати їх статус.

3 огляду на окреслені аспекти права комунальної власності на рослинні об’єкти, занесені до Зеленої книги України, пропонуємо таке його визначення: це право територіальної громади володіти, користуватися й розпоряджатися на свій розсуд та у своїх інтересах об’єктами, що визначені такими за критеріями належності до певної категорії, врахування їх статусу, територіальності й суспільного значення і, які належать громаді як безпосередньо, так і опосередковано - через органи місцевого самоврядування з дотриманням екологічних вимог. Закріплення у флористичному законодавстві цієї дефініції сприятиме його вдосконаленню.

\section{Список використаних джерел}

1. Андрейцев В. І. Екологічне право: курс лекцій в схемах; заг. ч. Київ : Вентурі, 1996. 218 с.

2. Гетьман А. Проблеми кодифікації законодавства про рослинний світ: деякі міркування (коментар до Закону України «Про рослинний світ»). Вісн. Акад. прав. наук Украӥни. 1999. № 3. С. 103-109.

3. Про внесення змін до деяких законодавчих актів України щодо розмежування земель державної та комунальної власності : Закон України від 06.09.2012 р., № 5245-VI. Відомості Верховної Ради України. 2013. № 36. Ст. 472.

4. Про місцеве самоврядування : Закон України від 21.05.1997 р., № 280/97-ВР. Відомості Верховної Ради Украӥни. 1997. № 24. ст. 170. 
Зигрій О., Ковальчук Ю., Кондрат Т.

Правове регулювання права власності на лісові угіддя та об'єкти рослинного світу

5. Про основні засади (стратегію) державної екологічної політики України на період до 2020 року : Закон України від 21.12.2010 р., № 2818-VI. Офіиійний вісник України. 2010. № 3. Ст. 158.

6. Про охорону навколишнього природного середовища : Закон України від 25.06.1991 р., № 1264-XII. Відомості Верховної Ради України. 1991. № 41. Ст. 546.

7. Про природно-заповідний фонд : Закон України від 16.06.1992 р., № 2456-XII. Відомості Верховної Ради Украӥни. 1992. № 34. Ст. 502.

8. Про розмежування земель державної та комунальної власності : Закон України від 05.02.2004 p., № 1457-IV. Відомості Верховної Ради України. 2004. № 35. Ст. 411.

9. Про рослинний світ : Закон України № 591-XIV від 09.04.1999 р. Відомості Верховної Ради України. 1999. № 22-23. Ст. 198.

10. Земельний кодекс України: науково-практичний коментар / Г. М. Беженар, Е. С. Бердніков, Л. О. Бондар та ін.; за ред. : А. П. Гетьмана, М. В. Шульги. 4-е вид., доп. Харків : Одіссей, 2008. 624 с.

11. Конституційний договір між Верховною Радою і Президентом України про основні начала організації і місцевого самоврядування в Україні на період до прийняття нової Конституції України від 08.06.1995р., № 1к/95-ВР. Відомості Верховної Ради України. 1995. № 18. Ст. 133.

12. Конституція України, від 28 червня 1996 р. Відомості Верховної Ради Украӥни. 1996. № 30. Ст. 141.

13. Кулинич П. Ф. Право власності на природні ресурси. Екологічне право України : акад. курс : підруч. Київ : Юрид. думка, 2005. Розд. 4. С. 67-92.

14. Кулинич П. Ф. Тенденції розвитку права власності на землю в сільському господарстві. Проблеми права власності та господарювання у сільському господарстві : моногр. Київ : Ін-т держави і права ім. В. М. Корецького, 2001. Розд. 3. С. 59-101.

15. Лісовий кодекс України. Від 21.01.1994 р., № 3852-ХІІ. Відомочті Верховної Ради Украӥни. 1994. № 17. Ст. 99.

16. Малышева Н. Р. Гармонизация экологического законодательства в Европе : моногр. Київ, 1996. 233 с.

17. Науково-практичний коментар Лісового кодексу України / за ред. Г. І. Балюк. Київ : Юрінком Інтер, 2009. $368 \mathrm{c}$.

18. Непийвода В. П. Правове регулювання суспільних відносин щодо лісів у контексті сталого розвитку : автореф. канд. юрид. наук. Київ, 2006. 22 с.

19. Носік В. В. Право власності на землю Українського народу : моногр. Київ : Юрінком Інтер, 2006. 544 с.

20. Постанова Кабінету Міністрів України «Про Зелену книгу України». № 1286 від 29.08.2002 p.

21. Постанова Кабінету Міністрів України «Про розмежування державного майна України між загальнодержавною (республіканською) власністю і власністю адміністративно-територіальних одиниць (комунальною власністю)», від 05.11.1991 р., № 311.

22. Про затвердження тимчасового порядку розмежування земель права державної і комунальної власності: Пост. КМУ від 01.08.2002 р., № 1482. Офіиійний вісник Украӥни. 2002. № 31. Ст. 1482.

23. Шемшученко Ю. С. В центрі уваги відділення - проблеми екологічного, господарського, аграрного та земельного права. Вісник Академії прав наук України. 2003. № 2/3. С. 521-534.

24. Юрчишин Н. Г. Реалізація права приватної власності на ліси : автореф. дис. канд. юрид. наук : 12.00.06. Київ, 2009. 18 с.

\section{References}

1. Andreycev, V. I. (1996). Ekolohichne pravo [Environmental law]. Kyiv: Venturi [in Ukrainian].

2. Hetman, A. (1999). Problem kodyfikacii zakonodavstva pro roslynyi svit: deiaki mirkuvannia [Problems of codification of flora legislation: some considerations (commentary to Zakon Ukrainy pro «Roslunnuy svit»)]. Visn. Acad. prav. nauk Ukrainy - Review of Law Sciences Academy of Ukraine, 3, 103-109 [in Ukrainian].

3. Zakon Ukrainy Pro vnesennia zmin do deiakuch zakonodavchuh aktiv Ukrainy rozmeshuwannia zemel derzhavnoi ta komunalnoi vlasnosti [Law of Ukraine «On Amendments to Certain Legislative Acts of Ukraine on the Delimitation of State and Communal Property Lands», 06.09.2012]. Verkhovna Rada of Ukraine. Kyiv: Parlam. vyd-vo [in Ukrainian].

4. Zakon Ukrainy Pro mistseve samovriaduvannia vid 21.05.1997 [Law of Ukraine «On Local Self-Government», No. 21/27/1997, № 280/97-BP ]. (1997). Vidomosti Verhovnoi Rady Ukrainy - Verkhovna Rada of Ukraine Review, 24, 70 [in Ukrainian].

5. Zakon Ukrainy Pro osnovny zasady (stratehiy) dershavnoy ekonomichnoy polityky na period do 2020 roky [Law of Ukraine "On the Fundamental Principles (Strategy) of the State Environmental Policy of Ukraine to 2020»] vid 21.12.2010 [in Ukrainian]. 
Цивільне право і цивільний процес. Сімейне право. Трудове право. Міжнародне приватне право. Господарське право. Господарсько-процесуальне право.

6. Zakon Ukrainy Pro ohorony navkolishniogo prurodnoho seredovuscha vid 25.061991 [Law of Ukraine «On Environmental Protection», dated 25.06.1991, № 1264-XII]. (1991). Vidomosti Verhovnoi Rady Ukrainy Verkhovna Rada of Ukraine Review, 41, 546 [in Ukrainian].

7. Zakon Ukrainy Pro prurodnio zapovidnyy fond vid 16.06 1992 [Law of Ukraine «On Nature Reserve Fund», dated 16.06.1992, № 2456-XII]. Vidomosti Verhovnoi Rady Ukrainy - Verkhovna Rada of Ukraine Review, 34, 502 [in Ukrainian].

8. Zakon Ukrainy Pro rozmezuvannia zemel derzavnoi ta komunalnoi vlasnosti [Law of Ukraine «On Delimitation of State and Communal Property Lands», dated February 05, 2004]. No. 14-57-IV. Vidomosti Verhovnoi Rady Ukrainy - Verkhovna Rada of Ukraine Review, 35, 411 [in Ukrainian].

9. Zakon Ukrainy Pro roslynnyi svit [Law of Ukraine «On the Plant World» No. 591-XIV of 09.04.1999]. Vidomosti Verhovnoi Rady Ukrainy - Verkhovna Rada of Ukraine Review, 22-23, 198 [in Ukrainian].

10. Zemelnyi kodeks Ukrainy: naukovo-praktychnyi komentar (2008) [Land Code of Ukraine: Scientific and Practical Commentary]/ G. M. Bezhenar, E. S. Berdnikov, L. O. Bondar et al.; edited by A. P. Hetman and M. V. Shulga]. Type 4, Ext. Kharkiv: Odissei [in Ukrainian].

11. Konstytuciinyi dohovir miz Verchovnou Radoiu I Prezydentom Ukrainy pro osnovnyi poczatok orhanizacii miscevoho samovraduvannai v Ukraini na period do pryinattia novoi Konstytucii (1995) [Constitutional agreement between the Verkhovna Rada and the President of Ukraine on the main principles of organization and local self-government in Ukraine for the period before the adoption of the new Constitution of Ukraine of 08.06.1995]. Vidomosti Verhovnoi Rady Ukrainy - Verkhovna Rada of Ukraine Review, 18, 133 [in Ukrainian].

12. Konstytucia Ukrainy [The Constitution of Ukraine], dated June 28, 1996]. Vidomosti Verhovnoi Rady Ukrainy Verkhovna Rada of Ukraine Review, 30, 141. [in Ukrainian].

13. Kulynych, P. F. (2005). Pravo vlasnosti na pryrodni resursy [The right of ownership of natural resources. Environmental Law of Ukraine: Acad. course: textbook]. Kyiv: Law. opinion [in Ukrainian].

14. Kulynych, P. F. (2001). Tendencii rozvytku prava vlasnosti na zemlu w silskomu hospodarstvi [Trends in the development of land ownership in agriculture. Problems of ownership and management in agriculture: monogr]. Kyiv: Inst. Of State and Law, Rozdil 3, 59-101 [in Ukrainian].

15. Lisovyi kodeks Ukrainy [Forest Code of Ukraine. From January 21, 1994], No. 3852-XII. Vidomosti Verhovnoi Rady Ukrainy - Verkhovna Rada of Ukraine Review, 17, 99 [in Ukrainian].

16. Malysheva, N. R. (1996). Harmonizacia ekolohichnoho zakonodavstva v EU [Harmonization of environmental legislation in Europe]. Kyiv [in Ukrainian].

17. Baliuk, G. I. (2009). Lisovyi kodeks Ukrainy: naukovyi komentar [Scientific and Practical Commentary on the Forest Code of Ukraine]. Kyiv: Yurinkom Inter [in Ukrainian].

18. Nepyvoda, V. P. (2006). Pravove rehuluvania suspilnych vidnosyn szczodo lisiv [Legal regulation of public relations in forests in the context of sustainable development: authoref. diss. on the image. of sciences. stupa. Cand. lawyer. Sciences]: 12.00.06. Kyiv [in Ukrainian].

19. Nosik, V. V. (2006). Pravo vlasnosti na zemlu ukrainskoho narodu [Ownership of the land of the Ukrainian people: monogr]. Kyiv: Yurinkom Inter [in Ukrainian].

20. Postanova KMU Pro zelenu knyhu [Resolution of the Cabinet of Ministers of Ukraine «On the Green Paper of Ukraine», No 1286, dated 29.08.2002]. [in Ukrainian].

21. Postanova KMU Pro rozmezuvania zemel... [Resolution of the Cabinet of Ministers of Ukraine "On the Distinction of State Property of Ukraine between State (Republican) Property and Property of AdministrativeTerritorial Units (Communal Property)»], No. 311 of 05.11.1991 [in Ukrainian].

22. Pro zaprovadzennia tymczasovoho poradku rozmezuvannia zemel [On approval of the temporary order of demarcation of land of state and communal property: Post. CMU of 01.08.2002], No. 1482. (2002). Ofitsiinyi Visnyk Ukrainy - Official Bulletin of Ukraine, 31, 1482 [in Ukrainian].

23. Shemshuchenko, Y. S. (2003). V centri uvahy viddilenia - problem ekolohicznoho, hospodarskoho, zemelnoho prava [The focus of the department is the problems of environmental, economic, agrarian and land law. Visyk Akademii pravovyh nauk Ukrainy - Bulletin of the Academy of Law Sciences of Ukraine]., 2/3, 521-534 [in Ukrainian].

24. Yurchyshin, N. G. (2009). Realizacia prava vlasnosti na lisy [Realization of the right of private ownership of forests: abstract. diss. on the image. of sciences degree of Candidate of Law Sciences: 12.00.06. Kyiv [in Ukrainian]. 